\title{
History of origin and development of replacement of plants crop rotations is in world agriculture
}

\author{
Natalia Kovalenko \\ State Scientific Agricultural Library of the National Academy of Agricultural Sciences of Ukraine, \\ Sector of Scientific on Research of Center of History of Agrarian Science, Kyiv \\ BoikoNP@ukr.net
}

SUMMARY

In practice of world agriculture a long ago the known problem of decline of harvests of agricultural cultures at their permanent growing, but scientific explanation of this phenomenon became possible only with appearance of natural sciences. At first the declines of harvests bound to the toxic action of root excretions cultures on her repeated sowing, with development of humus theory of feed of plants of diminishing of harvests at the permanent sowing began to explain impoverishment of soil on a humus.

During a few centuries the known farmers development the looks in relation to forming of scientific bases of construction of replacement of plants crop rotations in the world systems of agriculture, set history of their development and improvement. The analysis of influence of possibility of optimal satiation of replacement of plants crop rotations is conducted by agricultural cultures on the level of fertility of soil, water and nourishing modes and their productivity. For the terms of the insufficient moistening a positive action is marked black pair on the improvement of the water mode of soil in crop rotations.

In historiography the problem of introduction and mastering of replacement of plants crop rotations for the decision of scientific and practical tasks of agricultural production is represented in many-sided aspects, worked out and the recommended replacement of plants crop rotations that are base on zonal principle of development of world agriculture that passed the protracted term of test and counted on various specialization of economies. But for today development of scientific and technical progress requires intensification of agricultural production with the use of intensive crop rotations and growing of high-performance cultures.

Hereupon there was a necessity of realization of analysis of the systems of historical value of scientifically-practical knowledge about development and improvement of replacement of plants crop rotations, as it gives an opportunity to work out to recommending a production with the use of the most effective elements of the past on modern agrarian business and allows to forecast them on the future.

Keywords: world agriculture, replacement of plants crop rotations, duties of cultures, historical origin, historical development

\section{INTRODUCTION}

For today intensification of agricultural production requires the increase of culture of agriculture, that foresees introductions of measures, that present him scientifically reasonable system. Among them scientifically reasonable crop rotations that are her basic and irreplaceable link and occupy the special place after various favorable influence on fertility of soil and productivity of agricultural cultures have an important value (Primak et al., 2005).

In fact a crop rotation is a scientifically reasonable duty of agricultural cultures and fallows in time and on territory or only in time (Esenko, 2002). A duty in time is an annual or periodic change of cultures and clean pair in the certain field. A duty means on territory, that the landed array of crop rotation is divided into the fields, where annually by turns grow agricultural cultures and in each of these fields they alternate in time. A replacement of plants crop rotation is a type of crop rotation, in the structure of that the grain-crops of the continuous sowing occupy the not more than half of area of plough-land and alternate with the cultivated and leguminous cultures that grow on other areas (Zemlerobsztvo, 2008).

On the basis of crop rotations develop the systems of fertilizer, mechanical till of soil and defense of sowing from weeds, wreckers and illnesses (Primak et al., 2003). Unsystematic realization of these measures, without the account of growing in the field of previous and next agricultural culture, results in subzero efficiency and obstruction of the fields (Nagy, 2012). In scientifically reasonable crop rotations the objective laws of agriculture show up better, and their inhibition gives an opportunity to regulate the rotation of elements of feed of plants in agriculture.

It is set on the basis of long-term researches, that crop rotations provide the most rational use of croplands, material and labour resources, they are organizationallyterritorial basis of permanent agriculture (Jurkevics et al., 2011). Their violation and ignoring elementary requirements to the scientifically reasonable duty of cultures inflict irreparable harm to the effective conduct of agriculture. Crop rotations allow to develop effective technologies of growing of agricultural cultures taking into account their cross-coupling, and also after an action each of measures, that applies the nearest predecessors in sowing (Lebigy, 2004). Therefore the increase of efficiency of conduct of agriculture can be provided only due to mastering of scientifically reasonable crop rotations that answer certain natural and climatic terms and specialization of agricultural production.

Efficiency of application of crop rotations in the separate ground-climatic zones depends on next factors: places, to duration of growing, compatibility and periods of return of cultures in crop rotations taking into account the requirements of ecologically-intensive technologies, production of goods of plant-grower; roles black and busy fallows for intensifications of agriculture; degree of satiation of crop rotations by the, cultivated and technical grain-crops in the economies of different productive direction (Bojko and Szajko, 2002). Taking into account this exposure of optimal duty of graingrowing, cultivated and industrial crops in crop rotations recognition organizational (economies of different patterns of ownership and ménage) and natural terms, 
role and productivity of separate cultures depending on a fertilizer and certain ground-climatic terms takes on the special significance.

\section{MATERIALS AND METHODS}

Methodological principles contain the ground of methodological basis of scientific search, choice of approaches in relation to development of key trends of research and use of the system of methods in relation to an origin and development of replacement of plants crop rotations of world agriculture. In particular, research of history of the scientific providing of development of replacement of plants crop rotations is base on general principles of modern historical science - historical method and objectivity. The observance of these principles provided the exposures of factors, that had a positive or negative influence on becoming and development of replacement of plants crop rotations of world agriculture, assisted their reconstruction in the conditions of application of effective conduct of agriculture.

An important place in the system of methods occupies the method of the following that foresees generalization of works of predecessors and modern scientists in the branch of agricultural science. It gave an opportunity to analyze methodical works of a number of scientistsagrarians, methodologies and organizers of agricultural business and replacement of plants crop rotations in particular. Among them distinguished by the methodical and scientific achievements A.T. Bolotov (1738-1833), A.M. Komov (1750-1792), M.G. Pavlov (1793-1848), O.I. Sovetov (1826-1901), A.O. Stebut (183-1923, A.D. Teyer (1752-1828) and other.

As a result of synthesis of all accessible information there was certain presentation in relation to the state of development and improvement of replacement of plants crop rotations of world agriculture. The degree of introduction of the newest scientific achievements of scientists, by means of that an agricultural production is renewed by scientific innovations, is found out up to a point. The applied method of the system assisted realization of analysis of labours of scientists-agrarians, that conducted scientific searches in relation to replacement of plants crop rotations in the different countries of the world.

For qualificatory there were select principles that lean against the achievement of home and foreign science and histories of origin and development of replacement of plants crop rotations sent to objective and comprehensive illumination in world agriculture, taking into account important in a conceptual plan developments of scientists, theoretical conclusions and generalizations that assisted a comprehension and forming of fundamental scientific positions.

\section{RESEARCH RESULTS}

The origin of replacement of plants crop rotations is founded in XVI. century in Belgium and Holland. Of that time replacement of plants crop rotations provided replacement of the steam field sowing of forage grasses with the aim of increase of the productivity of stockraising, industry and commodity production. In 1566 in Italy labour of Torello of «Remark went out from agriculture» with suggestions in relation to introduction of replacement of plants crop rotations by complete reform of agriculture, in 1600 in France of scientist O. Serre also came forward for the wide use of replacement of plants crop rotations.

In XVII. century the English agriculturists of Gartlib and Plattes, that before had agricultural practice in Holland, developed the theory of replacement of plants crop rotations with the use instead of the steam field of green crops: to the turnip, clover and raigrass. In 1731 the known agriculturist $\mathrm{Dj}$. Tull published a book on a replacement of plants economy, and his follower Taunshend perfected the idea of replacement of plants crop rotations by growing in one field of turnip. Later some modified the replacement of plants crop rotation of Taunshend became known under the name «Norfolsk» crop rotations.

In many districts of England «Norfolsk» began effectively to apply of replacement of plants crop rotation: a clover is a winter wheat - forage root crops are a barley with occupied of clover. Such duty of cultures is typical correlation of areas of sowing of different groups of cultures in replacement of plants crop rotations, where the grain-growing are grown by $50 \%$, cultivated $-25 \%$ and leguminous cultures - 25\% (Prjanisnikov, 1962).

In XVIII. century replacement of plants crop rotations took the dominating place in agriculture of France, in XIX. century - Germany. For introduction of replacement of plants crop rotations the grain growing yielded to the place the economy with the developed stock-raising and including to the crop rotations of industrial and cultivated crops, except grain-growing. Development of stockraising induced to extend the sowing areas of long-term leguminous grasses and forage root crops.

In the second half of XVIII. of century basic principles of replacement of plants crop rotations were first set forth by one of founders of this theory, German scientist A.D. Teyer (Teyer, 1831). He asserted that at the beginning of our era replacement of plants crop rotations in that widely used an alfalfa and vegetable cultures dominated in the fence surrounding villages of Rome. The French scientist Gasparen also named replacement of plants crop rotations Latin or Roman, but principles of the Roman replacement of plants crop rotations were not clearly set forth and in course of time appeared forgotten.

In the countries of Western Europe replacement of plants crop rotations began widely to apply a century in a middle XIX. The use of «Norfolsk» of crop rotation assisted the increase of agriculture of England, Belgium, Germany, Netherlands, where in the middle of XIX. of century the productivity of grain-crops in replacement of plants crop rotations rose more than in two times and presented 1,6-1,7 tons are on a hectare (Narcissov, 1982). In the middle of XX. of century in these countries of introduction of replacement of plants crop rotations in combination with the use of progressive agrotechnical measures (bringing of mineral fertilizers, introduction of new productive varieties and hybrids, improvement of till of soil) assisted the increase of productivity of grain-crops of to 3,5-4,3 tons are on a hectare.

Theory of replacement of plants crop rotations, adjusted to the natural terms of Russia in 1867 a developed a scientist-agriculturist O.I. Sovietov, but, except for some districts of country, replacement of plants crop 
rotations did not inculcate in general. Trying to adjust replacement of plants crop rotations to the terms of Russia, O.I. Sovietov underlined that peculiar large flexibility them (Sovietov, 1950). In Germany and Austria, in particular, introduction of replacement of plants crop rotations was not accompanied by such considerable, as in England, by reduction of areas of sowing of grain-crops. As retreat from the hard requirements of replacement of plants crop rotations was assumed by the repeated sowing of grain-crops (two winter-annual or winter and furious crops), in the live farming abandoned a clover during two years of the use. Mostly one of the fields in replacement of plants crop rotations occupied a clover and other leguminous grasses, however there were replacement of plants crop rotations without long-term grasses with sowing of one-year leguminous or leguminous and cereal cultures on a green feed, hay (vetch, one-year grasses) or on grain (peas, bobs, kidney bean) (Pavlyuk, 1991).

In Russia a considerable contribution to development of theoretical bases of replacement of plants crop rotations was done A.T. Bolotov (Bolotov, 1771) and I.M. Komov (Komov, 1788), what defined bases of replacement of plants crop rotations. Their essence was erected to the observance of next principles: all agricultural lands were occupied by the agricultural sowing with complete abandonment from clean pair; grew not only graingrowing cultures, that exhaust soil but also cultivated and long-term leguminous grasses that enrich soil, in an even proportion; did not allow in one field the repeated sowing of cultures of one group even two years in succession; annually there were on duty cultures that enrich and exhaust soil; used natural forage lands under plough-land, where it is possible to organize the production of forage.

Komov was sure of that success of the productivity of agriculture depends on a stock-raising and worked out a six-course crop rotation with the use of grasses: furious with occupied of long-term grasses - long-term grasses are long-term grasses - long-term grasses are winter crops - cultivated. A scientist pointed the obligatory constituents of replacement of plants crop rotations: occupied long-term leguminous grasses and root crops; replacement clean pair sowing of root crops; piling up in economies and bringing is in the fields of plenty of pus.

An important value is spared to adaptation of replacement of plants crop rotations to the different climatic terms. In 1860 I.O. Sovietov in labour «About breeding of forage grasses in the fields» grounded the value of sowing of long-term grasses in replacement of plants crop rotations for the increase of the productivity of stock-raising and direct method of proceeding in the fertility lost by soil. However, a scientist specified on the necessity of till of long-term grasses for replacement of plants crop rotations in accordance with the terms of the sufficient moistening, where get the high harvests of this culture. A.O. Stebut underlined uselessness of busy fallow in the conditions of the insufficient moistening and fallaciousness of categorical requirements of replacement of plants crop rotations - general liquidation of clean fallows, extremely necessary in a droughty steppe zone (Stebut, 1882).

Attempts to carry replacement of plants crop rotations in the fields of Russia repeatedly conducted in the end
XVIII. and at the beginning XIX. of century. Replacement of plants crop rotations inculcated in the western districts of Ukraine and Belarus, some provinces of Russia (Moscow, Smolensk, Yaroslavl) and the Baltic States. As active propagandists of replacement of plants crop rotations came forward A.T. Bolotov, O.M. Engelgardt, I.O. Levshin, I.A. Linovskiy, O.P. Ludogovskiy, M.G. Pavlov, D.M. Poltoratskiy, P.M. Preobrajenskiy, A.M. Roznatovskiy, A.A. Samarin, O.I. Sovietov, S.M. Usov, D.P. Shelehov and other. However in most cases popularization of replacement of plants crop rotations in Russia did not score a success, and their practical mastering in the central, east and south districts of country often ended with a failure (Zubec et al., 2005).

The features of export policy of the state are certain one of considerable reasons that restrained introduction of replacement of plants crop rotations in Russia. Basic commodity foods of Russian agriculture at that time were grain and partly flax. Replacement of plants crop rotations did not provide the increase of sowing areas of grain-crops, and even abbreviated them, comparatively with the steam three-field crop rotations. At the terms of extensive Russian agriculture growing appeared also not justified in the replacement of plants crop rotation of $25 \%$ of the cultivated cultures. As a large obstacle severe natural terms came forward in introduction of replacement of plants crop rotations, especially droughts that recurred often, and abandonment, from clean pair on greater part of territory of country at that time was fully impossible. On the unfertilized and badly treated soils the concerned pairs resulted in the receipt of subzero harvests of winter-annual rye and winter wheat.

In those districts of Russia, where grew a clover and cultivated cultures, sowing in crop rotations placed not on principle replacement of plants: long-term grasses used not alone, but two years; in crop rotations kept one field clean pair («Yaroslavl» of four-course and «Volokamsk» of eiht-course crop rotation); assumed the repeated sowing of cereals, and sometimes and the cultivated cultures in one field two years in succession. Local natural and economic terms entailed retreats from the «classic» West-European replacement of plants crop rotations and did not reduce efficiency of the use of earth. However, on the basic field arrays both in XVIII., XIX. and in first third of XX. of century undividedly steam crop rotations dominated with all their defects.

M.G. Pavlov a law named replacement of plants a natural law and considered him the first principle for the stowage of crop rotations. A scientist underlined that replacement of plants crop rotations most befitted for ideal agriculture, but notarized, that the improvement of agriculture can develop to unfinishedness and agriculture can not be limited to the already certain achievements (Pavlov, 1837). O.I. Sovietov believed in progressive application of replacement of plants crop rotations introduction of that will assist the bloom of world agriculture and cattle breeding (Hrapkov, 1981). But he considered agronomical science imperfect that requires the decision of many problems in relation to introduction of replacement of plants crop rotations. 


\section{CONCLUSIONS AND PROSPECTS OF FURTHER RESEARCHES}

Possibility of growing of various cultures, considerable increase of the productivity of agriculture, increase of productivity of grain and technical crops, large flexibility of replacement of plants crop rotations is all did them most adjusted to the terms and requirements of agricultural production. Under act of replacement of plants crop rotations, deeper and assiduous till of soil, wide and systematic application of fertilizers the level of fertility of soils rose, their general culture grew, substantially harvests and general productivity of agriculture increased in the countries of Western Europe, that inculcated them. At the same time the change of composition and correlation of cultures within the limits of four-course crop rotation was not able fully to satisfy the necessities of economies. Therefore began to inculcate crop rotations with the greater rotary press of the fields. Introduction of replacement of plants crop rotations was only the first step on the way of scientific and technical progress in world agriculture.

Quite another position with introduction of replacement of plants crop rotations was in Russia, especially in, her east and south central districts. The attempts of transference of such crop rotations to Russia on the West-European standard, as a rule, ended with a failure. One of important reasons that hindered to introduction of replacement of plants crop rotations was that the areas of grain-crops did not increase in them, and diminished even. A serious obstacle to introduction of replacement of plants crop rotations were more severe natural terms, especially frequent droughts that as a result of reduction of areas clean a pair over on large territory was brought to the considerable shortages of harvest. On unfertilized and, in addition, the badly treated earth of busy fallows got the subzero harvests of winter-annual rye and winter wheat, that is why in Russia, dominating was remained by the three-field crop rotations up to 1917 . Systematic introduction of replacement of plants crop rotations in Russia and Ukraine began in $30^{\text {th }}$ of XX. of century, when the period of mass transition came from the three-field crop rotations to the multi-field cultivated and replacement of plants crop rotations.

The important signs of replacement of plants crop rotations are mark throwing of natural forage lands and their converting open into plough-land, except for part of high-performance meadows; growing of the green, most advantageous crops is in the fields; liquidation of clean fallows their replacement leguminous grasses; a duty of grain-crops is with leguminous and cultivated cultures. Passing to the replacement of plants crop rotations had a progressive value, because in them major principle of replacement of plants - severe duty of different stuck to after biological features and agrotechnics of growing of cultures. Introduction to the replacement of plants crop rotation of four groups of cultures instead of two opened wide possibilities for application of plenty of variants of replacement of plants crop rotations. For example, due to mushroom growth in the first half of XIX. of century of saccharine industry in such crop rotations included sugar beets.

Researches on this subjects require continuation with the aim of finding out of role of the Ukrainian and foreign scientists and practical workers in development of becoming of theoretical bases of replacement of plants crop rotations. Development and introduction of the replacement of plants crop rotations, adapted to the different climatic and economic terms of country, that answer ecological and intensive direction of world agriculture, ground, appears for modern science and practice an actual task.

\section{REFERENCES}

Бойко, П. І.-Сайко, В. Ф. (2002): Сівозміни у землеробстві України. Київ. Аграрна наука. 146.

Болотов, А. Т. (1771): О разделении полей - Труды вольного экономического общества. Санкт-Петербург. 178.

Єщенко, В. О. (2002): Загальне землеробство. Термінологічний словник. Умань. УВПП. 176

Храпков, С. А. (1981): Первый в России: об А. В. Советове. Москва. Колос. 96

Юркевич, С. О.-Коваленко, Н. П.-Бакума, А. В. (2011): Агробіологічні основи сівозмін Степу України - монографія. Одеса. ВМВ. 237.

Комов, И. М. (1788): О земледелии. Москва. 112.

Лебідь, С. М. (2004): Наукові основи агропромислового виробництва в зоні Степу України. За редакцією М. В. Зубця. Київ. Аграрна наука. 844.

Надь, Я. (2012): Кукурудза. Вінниця, ФОП Корзун Д. Ю. 224-229.

Нарциссов, В. П. (1982): Научные основы систем земледелия. Москва. Колос. 328

Павлов, М. Г. (1837): Курс сельского хозяйства. Москва. 221.

Павлюк, С. П. (1991): Традиційне хліборобство України - агротехнічний аспект. Київ. Наукова думка. 224.
Примак, І. Д.-Вергунов, В. А.-Рошко, В. Г. (2005): Наукові основи землеробства - підручник. Біла Церква. БДАУ. 408.

Примак, І. Д.-Рошко, В. Г.-Демидась, Г. І. (2003): Раціональні сівозміни в сучасному землеробстві. Біла Церква. БДАУ. 384.

Прянишников, Д. Н. (1962): Севооборот и его значение в поднятии урожайности - Об удобрении полей и севооборотах - избранные статьи. Москва. Издательство Министерства сельского хозяйства РСФРС. 28-52.

Советов, А. В. (1950): О системах земледелия - избранные сочинения. Москва. Сельхозгиз. 235-419.

Стебут, И. А. (1882): Основы полевой культуры и меры к ее улучшению в России. Москва, Издательство книгопродавца А. Л. Васильева. 483.

Тэер, А. Д. (1831): Основания рационального сельского хозяйства. Москва. Ч. ІІ. 27-138.

Землеробство. Терміни та визначення понять - ДСТУ 4691:2006 - Національний стандарт України (2008): Київ. Держспоживстандарт України. 17.

Зубець, М. В.-Вергунов, В. А.-Власов, В. І. (2005): Землеробство України: від праслов'ян через події XIX і XX століть до наших днів. Київ. Аграрна наука. 280 